\title{
COMPLEX RADIOLOGICAL DIAGNOSIS OF OSTEONECROSIS OF FACIAL BONES IN DESOMORPHINE DEPENDENCE PATIENTS ON THE PREOPERATIVE STAGE OF TREATMENT
}

\author{
Babkova A.A. ${ }^{1}$, Serova N.S. ${ }^{1}$, Medvedev Yu.A. ${ }^{2}$
}

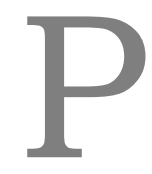

urpose. To determine the diagnostic efficiency of methods of complex radiological diagnosis (OPG, conventional radiography, MSCT, CBCT) in the evaluation of osteonecrosis in patients on preoperative stage.

Methods and materials. Orthopantomography, radiography of the skull, MSCT and CBCT were performed on 108 patients $(100 \%)$ in the preoperative stage. Also 25 patients $(21 \%)$ underwent radionuclide diagnostics: planar bone scan, SPECT.

Results. The application of complex highly informative radiological methods (MSCT, $\mathrm{CBCT}$, radionuclide diagnostics) in desomorphine dependence patients at the preoperative stage of treatment enables full investigation of character and the prevalence of the pathological process, to plan further tactics of surgical treatment.

Conclusions. Thus the diagnostic efficiency parameters at the preoperative stage for MSCT were: the sensitivity $-98,1 \%$, the specificity $-99,6 \%$, the accuracy $-98,8 \%$, for CBCT were: the sensitivity $-97,3 \%$, the specificity $-99,1 \%$, the accuracy $-98,4 \%$, for orthopantomography: the sensitivity $-78,6 \%$, the specificity $-76,3 \%$, the accuracy $-77,4 \%$, for skull $x-$ ray: the sensitivity $-61,1 \%$, the specificity $-59,2 \%$, the accuracy $-60,2 \%$.

Keywords: osteonecrosis, multislice computed tomography, orthopantomography, desomorphine, cone-beam computed tomography, radionuclide diagnostics.

Corresponding author: Babkova A.A., an4i1@yandex.ru

For citation: Babkova A.A., Serova N.S., Medvedev Yu.A. Complex radiological diagnosis of facial bones in desomorphine dependence patients on the preoperative stage of treatment. REJR 2019; 9(1):16-26. DOI:10.21569/2222-7415-2019-9-1-16-26.

Received: $\quad 19.01 .19 \quad$ Accepted: $\quad 06.02 .19$

\section{КОМПАЕКСНАЯ АУЧЕВАЯ АИАГНОСТИКА ОСТЕОНЕКРОЗА АИЦЕВОГО СКЕАЕТА У ПАЦИЕНТОВ С АЕЗОМОРФИНОВОЙ ЗАВИСИМОСТЬЮ НА АООПЕРАЦИОННОМ ЭТАПЕ АЕЧЕНИЯ}

\author{
Бабкова А.А. ${ }^{1}$, Серова Н.С. ${ }^{1}$, Медведев Ю.А. ${ }^{2}$
}

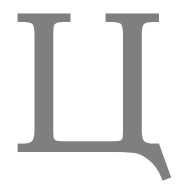

ель исследования. Определить диагностическую эффетивность методов компцексной цучевой диагностики (ОПТГ, рентгенография, МСКТ, КАКТ) в выявцении остеонекрозов у пациентов на дооперацционном этапе.

Материалы и методы. Ортопантомография, рентгенография черепа, МCKT, КАКТ были проведены 108 пациентам (100\%) на дооперационном этапе. Также 25 пациентов (21\%) подверглись радионуклидным методам диагностики: планарная остеосцинтиграфия, ОФЭКТ.

Результаты. Применение комплекса высокоинформативных рентгенологических методов (МСКТ, КАКТ, радионуклидные методы диагностики) у пациентов с дезоморфиновой зависимостью на дооперационном этапе цечения позволяет полноцнно определить характер, распространенность патологического процесса, спланировать тактику хирургического мечения.

Выводы. Таким образом показатели диагностической эффективности МСКТ составили: чувствительность - 98,1\%, специфичность - 99,6\%, точность - 98,8\%, дАя 
КАКТ: чувствительность - 97,3\%, специфичность - 99,1\%, точность - 98,4\%, для ортопантомографии: чувствительность - 78,6\%, специфичность - 76,3\%, точность - 77,4\%, для обзорной рентгенографии черепа: чувствительность - $61,1 \%$, специфичность $59,2 \%$, точность - 60,2\%.

К^ючевые слова: остеонекроз, мультиспиральная компьютерная томография, ортопантомография, дезоморфин, конусно-лучевая компьютерная томография, радионуклидная диагностика.

Контактный автор: Бабкова А.А., an4i1@yandex.ru

Для иитирования: Бабкова А.А., Серова Н.С., Медведев Ю.А. Комплексная лучевая диагностика остеонекроза лииевого скелета у паииентов с дезоморфиновой зависимостью на доопераиионном этапе лечения. REJR 2019; 9(1):16-26. DOI: 10.21569/2222-7415-2019-9-1-16-26.
Статья получена:
19.01.19
Статья принята:
06.02.19

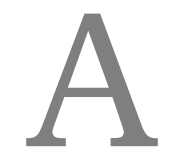

$\mathrm{t}$ this moment, in the scientific literature there are much more reports of the occurrence of osteonecrosis of the bones of the facial skeleton in patients who use synthetic drug such as desomorphine. Previously, this pathological process meant the development of atypical osteomyelitis of the jaw, but now the term "osteonecrosis" of the bones of the facial skull is more often used [1]. Desomorphine is a the drug witch manufactured by extraction from codeine-containing drugs, which could be freely purchased in the pharmacy network in the territory of the Russian Federation, up to 01.06.2012. This drug was first synthesized in 1933 in the United States. Being a stronger analgesic than morphine, this drug because of the rapid occurrence of drug addiction has not found proper medical application. A solution of desomorphine produced using different ingredients, such as codeine, gasoline, soda, iodine, acetone, red phosphorus, etc., contaminated with intermediate products of synthesis, is an unstable substance without the possibility of its transportation [2]. Since 2003, desomorphine has been widely used, taking the second place in the total volume of drugs consumed in the territory of the Russian Federation after heroin [3]. Thus, up to 2011-2012 there was an annual steady increase in the number of users of desomorphine. Despite the interdiction imposed on 01 June 2012 on over-thecounter sales of codeine preparations on the territory of the Russian Federation, in the leading medical institutions in the country daily treated patients with the consequences of using this drug.

In addition to various highly toxic chemicals, the drug also includes red phosphorus, which causes the development of atypical osteonecrosis of the facial skull bones [4]. This type of osteonecrosis in the clinical picture is similar to the cases of phosphoric osteomyelitis of the jaws previously described in the literature, associated with the phosphoric production of matches in the late 19 th century [5].

Typical for this osteonecrosis are the prolonged course of the pathological process with resistance to standard drug treatment is characteristic, the tendency to rapidly spread to adjacent anatomical structures, which leads eventually to persistent deformities of the maxillofacial region and subsequent invalidism of patients, which, as a rule, include persons of young and able-bodied age [6].

Treatment consists in carrying out radical surgical interventions depending on the volume of affected structures, within healthy tissues, with one-stage or delayed installation of nikelid titanium implants in place of resected bones [7].

In order to obtain the optimal result of surgical treatment, timely and detailed assessment of pathological changes in bone tissue, correct interpretation of the prevalence of osteonecrosis zones, involvement in the process of both the bones of the maxillofacial region and other parts of the skeleton is necessary.

Diagnosis of osteonecrosis and subsequent planning of surgical intervention is currently based on the results of the use of complex methods of radioligical examinations such as orthopantomography (OPG), radiography of the skull in direct projection, multislice computed tomography (MSCT), cone-beam computed tomography $(\mathrm{CBCT})$, in some cases, also the bone scan and SPECT.

Orthopantomography (OPG) in the preoperative stage of treatment was used in 108 patients $(100 \%)$. OPT allows to assess the general condition of the entire dentoalveolar system (bone tissue, teeth, periodontium, parodontium), approximate prevalence of osteonecrotic process, also gives a description of the wells of the removed teeth, al- 
lows to determine the presence, nature, localization of fracture, areas of osteosclerotic changes in bone structure, bone sequestration, periosteal reaction.

OPG is an affordable method of diagnosis, but has a number of disadvantages: projection distortion, additional shadows (superposition effect), poor visualization of the frontal group of teeth, upper jaw, sinuses. Thus, orthopantomography requires a mandatory addition of other more informative methods of radiation diagnosis (MSCT, CBCT) [8].

Radiography of the skull in a direct projection was performed in two stages of diagnosis. This method makes it possible to assess the condition of the bones of the vault of the skull, body, branches and processes of the mandible [8]. In this group of patients, radiography of the skull in a direct projection allowed to give an overall assessment of the condition of the skull bones, fracture of the mandible.

However, the spectrum of traditional x-ray techniques allows to obtain a single-projection image of the anatomical area with superposition effect, projection distortions [8]. Thus, they have a number of limitations in assessing the prevalence, nature of pathological changes, involvement in the process of surrounding tissues.

Multislice computed tomography (MSCT) is a modern method of radiation diagnostics, which allows to obtain multislice, layered image of the anatomical area, with the possibility of subsequent processing of the obtained images, constructions of multiplanar reconstructions, measurements of length, angles, volumes, density estimation on the Hounsfield scale, including the assessment of soft tissue components [9].

MSCT in the diagnosis of osteonecrosis in patients with desomorphine drug addiction was the main, the most informative method of research. MSCT makes it possible to determine the presence of osteonecrosis of the maxillofacial area, changes in the accompanying anatomical structures, to give a full characteristic of bone tissue, the prevalence of the pathological process, including in the upper jaw [10]. MSCT in this group of patients was used at pre - and postoperative stages of diagnosis. The limitation of the method is the relatively high cost of its implementation. In foreign literature, the issue of the use of MSCT in the diagnosis of osteonecrosis of the facial skull bones of various etiologies is sufficiently covered. However, the description of phosphate osteonecrosis in patients with desomorphine dependence have little impact due to the fact that this type of drugs in the US and the EU hardly used [11].

At the moment, there is no single approach to the use of MSCT in maxillofacial surgeons and dentists. Also, doctors-radiologists do not have uniform standardized protocols of processing and analysis of the received $\mathrm{x}$ - ray data at the pre-and postoperative stages.

In some cases, cone-beam computed tomography $(\mathrm{CT})$ was performed in addition to MSCT in patients at the initial consultation stage and in the postoperative period. The method combines the simplicity of the study of traditional dental panoramic x-ray and high-quality computed tomography. A distinctive feature of the MSCT is a lower radiation load ( 2 times lower), the cost of the study, the severity of artifacts from metal structures, the ability to conduct research in FaceScan mode [12].

Osteoscintigraphy was additionally applied in patients with complaints of pain and dysfunction in the knee and hip joints. The method allows to identify areas of osteonecrotic changes in bone structure, to appreciate the prevalence of the pathological process that goes beyond the maxillofacial area.

\section{Materials and methods.}

In the period from 2014 to 2018 , a total of 108 drug addicts with a history of abuse codeincontaining synthetic drugs such as desomorphine were evaluated at the Clinics of the First Moscow State Medical University named after I. M. Sechenov. The age of patients varied from 18 to 48 years. The median age was 28 years. Among the patients, the number of women was $11(10,1 \%)$, men - 97 (89,9\%). The duration of administration of desomorphine in this group of patients ranged from 2 months to 10 years.

All subjects ( $\mathrm{n}=108 ; 100 \%)$ went through a complete clinical, microbiological, and X-ray evaluation. Radiological diagnostic methods included anteroposterior skull X-ray, panoramic radiography (OPG), multispiral computed tomography (MSCT), cone-beam computed tomography and bone scintigraphy. Facial skull MSCT performed in the 108 subjects included various multiplanar and three-dimensional (3D) reconstructions of obtained images with subsequent analysis. 108 patients $(100 \%)$ underwent CBCT with FaceScan program. 25 patients $(21 \%)$ underwent radionuclide bone scintigraphy with the 99mTcPyrphotech radiopharmaceutical (planar scintigraphy, SPECT). The study was carried out using a gamma camera, according to the standard technique, with subsequent modified image processing. As a result of this complete clinical, X-ray evaluation, 108 patients were diagnosed with a "Toxic phossy osteonecrosis" of respective facial skull bones.

\section{Results.}

Clinical, radiological data obtained in the 108 subjects demonstrated atypical bone osteonecrosis of the facial skull with a characteristic prolonged course of the disease resistant to standard pharmacological treatment. Physical examination data included gum recession, exposed alveolar 
processes of the jaws, and open areas of bone tissue that had a typical dirty-grey or yellow-brown color (fig. $1(\mathrm{a}, \mathrm{b}))$.

Radiological diagnostics revealed empty tooth sockets without signs of osteolysis in 108 patients, as well as a widened periodontal fissure with sclerotic end plates in 57 subjects (52,8\%). In 39 patients $(36,1 \%)$ findings included massive diffuse periosteal muff-like deposits, predominantly in the lower jaw region, formation of extensive zones of sequestration, and osteoporotic and osteosclerotic areas alternating in the bone tissue.

It was found that in 34 patients $(31,5 \%)$ osteonecrosis sites were located in the upper jaw area, in $49(45,4 \%)$ - in the lower jaw area, in
$23,1 \%$ of cases $(n=25)$ the pathological process was spread on both jaws. The areas of osteosclerosis were determined from the data of mainly OPG in more than half of cases $(n=63 ; 58,3 \%)$. Their localization corresponded to the areas of angles, branches of the lower jaw, locally around the source of destruction, or their combination. Less often, osteosclerosis of the whole body of the lower jaw was noted, without or with the involvement of branches and angles on both sides. In a number of cases, osteosclerosis was determined in the region of the coronary and condylar processes of the lower jaw. The fracture line was detected in 22,2\% $(n=24)$ patients, mainly in the area of corners, branches and the body of the lower jaw (Fig.2).

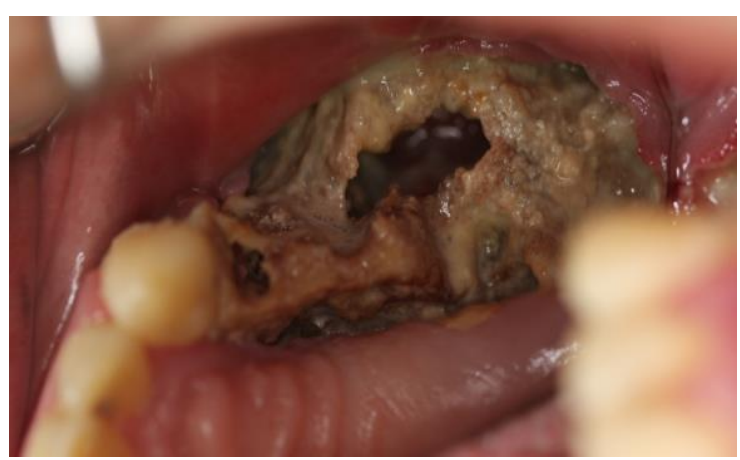

Fig. 1 (Рис. 1)

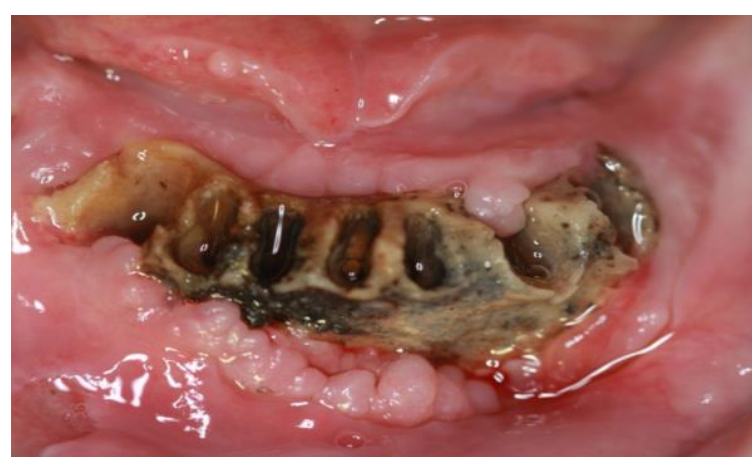

Fig. 2 (Рис. 2)

Fig. 1. Photos.

Visual examination reveals a recession of the gum and an exposed alveolar process of the upper (a) and lower (b) jaws.

\section{Рис. 1. Фотографии.}

Визуальный осмотр позволяет определить рецессию костной ткани челюстей, выявить оголенные участки альвеолярных отростков верхней (а) и нижней (б) челюстей.

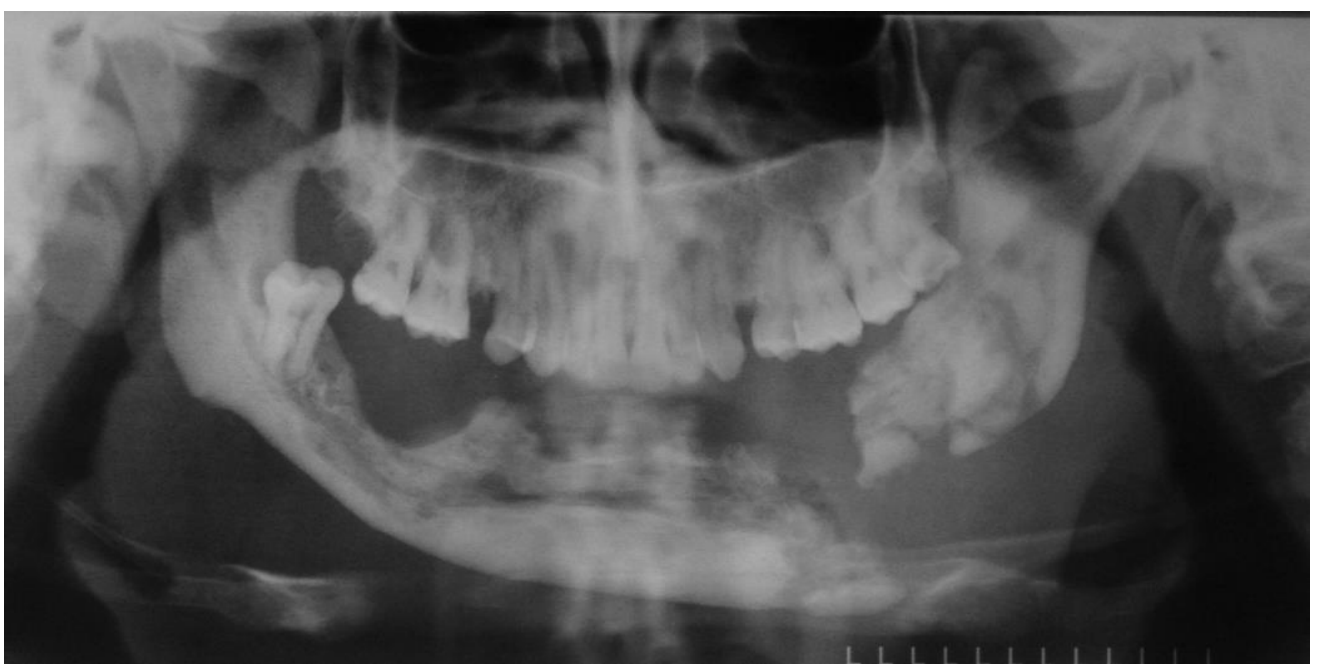

Fig. 2 (Рис. 2)

\section{Fig. 2. Panoramic radiograph.}

Destruction of the body of the lower jaw, areas of sequestration, and the pathological fracture on the left side can be seen.

\section{Рис. 2. Ортопантомограмма.}

Определяются деструкция тела нижней челюсти, участки секвестрации, патологический перелом слева. 
The periostitis was detected in patients in $37 \%$ of cases $(n=40)$. The intensity of periosteal stratifications, the degree of their expression was different: in $8,3 \%(\mathrm{n}=9)$ there was a linear type of periostitis, sometimes passing into lamellar, in $67,6 \%$ $(n=50)$ the layered so-called bulbous type was determined. According to traditional X-ray methods, sequestration was determined in 32 cases $(29,6 \%)$, but the nature of the sequesters, localization, penetrating character was not reliable due to limitations of these methods (projection distortions, errors reaching 20\%). Changes in the periodontal gap were noted in 62 patients $(57,4 \%)$ : with its expansion $(n=35 ; 32,4 \%)$, its enlargement and sclerosing $(n=11 ; 10,2 \%)$, sclerosing without ex- methods, MSCT and CBCT allowed to accurately assess the localization of osteonecrosis foci: in $49,1 \%(n=53)$ cases in the mandible, in $23,1 \%$ $(n=25)$ in the upper jaw region, in $30(27,8 \%)$ patients pathological process captured both jaws. MSCT and CBCT also revealed the involvement of other bones of the facial skeleton in the pathological process $(n=42 ; 38,9 \%)$. These methods allowed to evaluate changes in the structure of the bone tissue of the maxillofacial region: alternation of osteosclerosis zones with osteoporosis zones - the so-called "soap foam" pattern in 29 patients $(26,9 \%)$. Foci of osteonecrosis according to MSCT (CBCT) had an irregular shape, a fusing character. There was a lack of a clear demarcation zone. Ac-

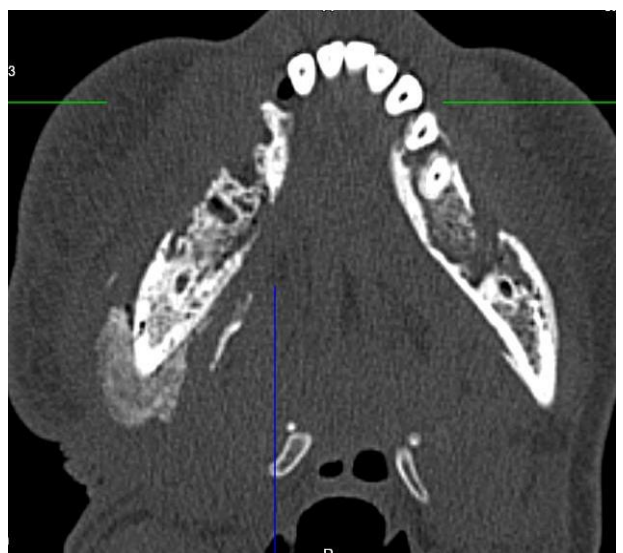

Fig. 3 a (Рис. 3 a)

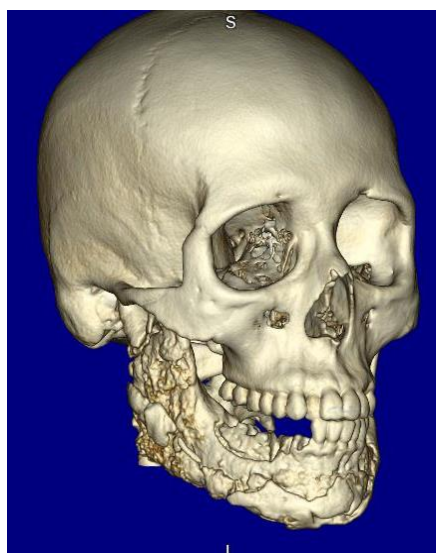

Fig. 3 b (Рис. 3 б)

\section{Fig. 3. MSCT. Axial (a), coronal (b) reconstructions.}

In the region of the lower jaw, irregular osteosclerosis is noted, mainly on the right. In the area of the body, angle, branch, processes of the lower jaw on the right, massive fringing, sometimes broken periosteal layers are visualized.

\section{Рис. 3. МСКт. Аксиальная (а), корональная (б) реконструкции.}

В теле нижней челюсти отмечается неравномерный остеосклероз, преимущественно справа. В теле, углу, ветви, отростках нижней челюсти справа определяются массивные, местами разорванные слоистые периостальные наслоения.

pansion $(\mathrm{n}=9 ; 8,3 \%)$, in 5 patients $(4,6 \%)$ there was a narrowing of the periodontal gap. Holes of previously removed teeth were not detected in 64 cases $(59,3 \%)$, in 20 patients $(18,5 \%)$, there were holes without signs of sclerosis in $31,5 \% \quad(n=34)$ their sclerosis was noted. In $22,2 \%(n=24)$ cases the increase in the size of the lower jaw due to laminated periostitis was determined. However, it was impossible to determine the exact size, thickness of the alveolar and palatine processes of the upper jaw, the size of the mandible, the structure and density of the bones of the maxillofacial region, and the state of the maxillary sinuses, according to the traditional radiographic methods used.

When conducting MSCT and CBCT $(n=108$; $100 \%)$ the criteria for evaluating diagnostic studies were similar. In contrast to traditional X-ray cording to MSCT and CBCT sequestrants were detected in 42 patients (38,9\%), spongy, cortical, mixed in some cases. By using MSCT fistula passages in soft tissues were determined in 80 patients $(74 \%)$, while part of the sequestration was attributed to the penetrative type ( $n=4 ; 3,7 \%)$. MSCT (CBCT) allowed to more accurately assess the nature and location of the periosteal reaction, including in the frontal sections of the jaws, maxillary sinuses, which was impossible with traditional radiographic techniques. According to MSCT (CBCT), the phenomenon of periostitis were detected in 64 patients $(59,2 \%)$. In 23 cases $(46 \%)$, the layered nature of the periosteal layers, predominantly in the region of the lower jaw, was defined, which covered the bone as a "clutch" on all sides (fig.3). When the upper jaw is injured, the periostitis captures the internal surface of the 


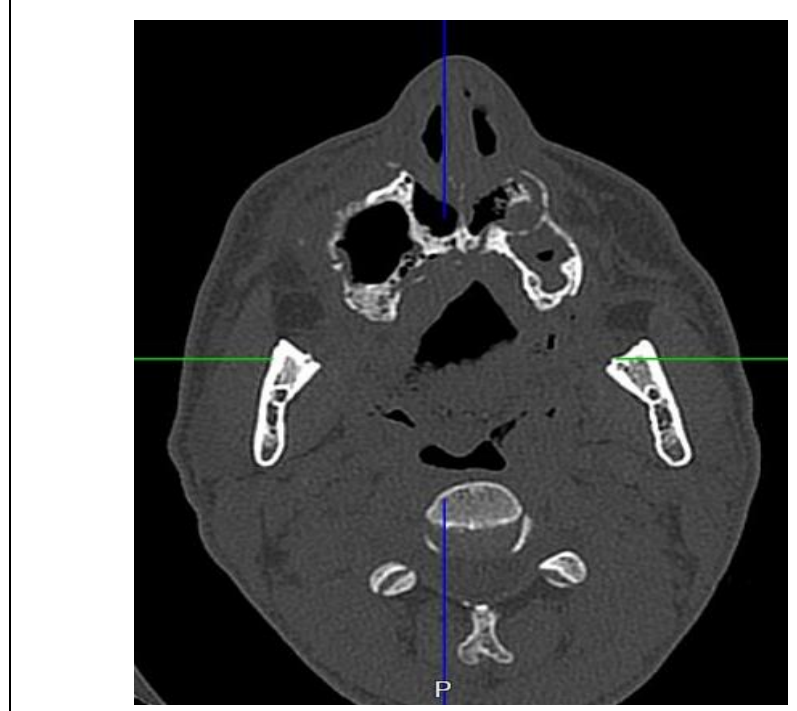

Fig. 4 a (Рис. 4 a)

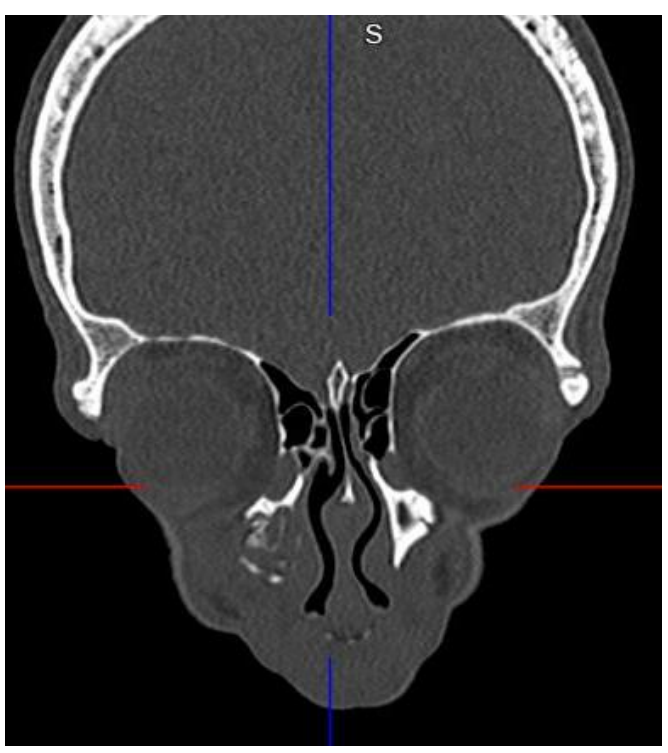

Fig. 4 с (Рис. 4 в)

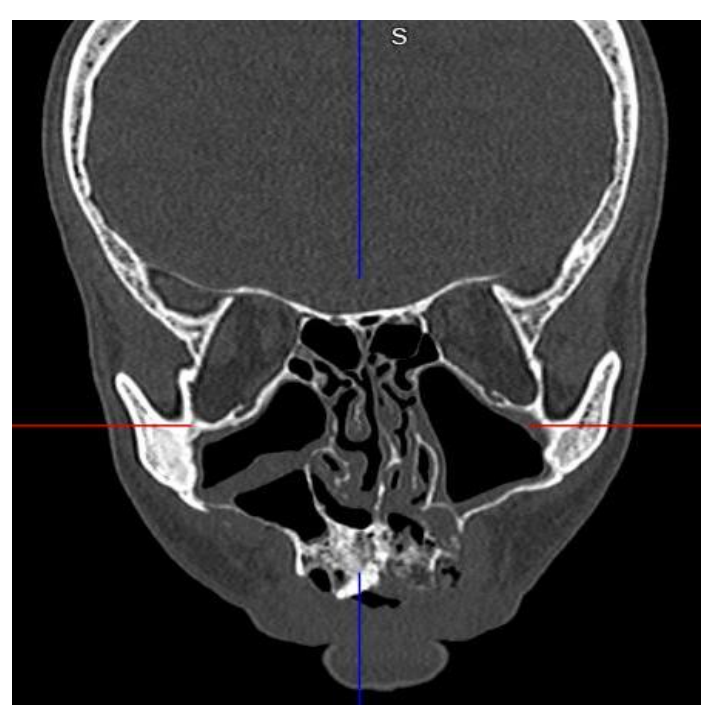

Fig. 4 b (Рис. 4 б)

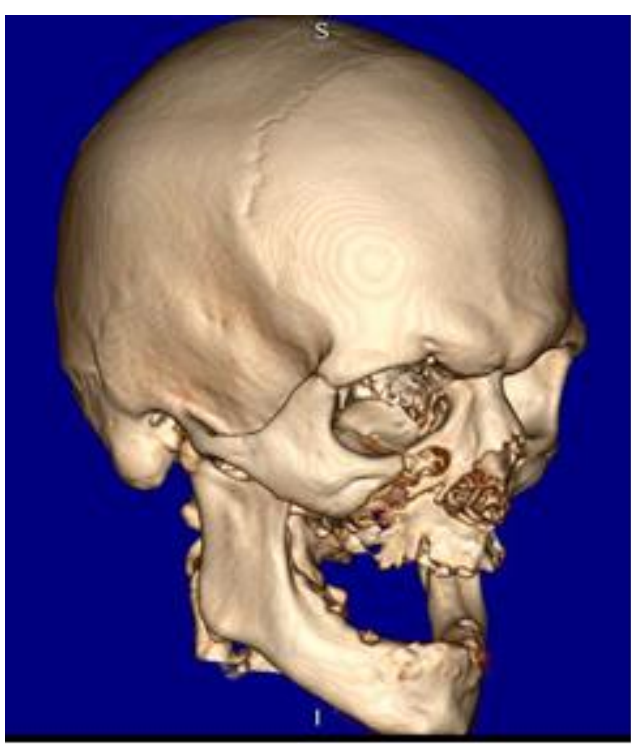

Fig. $4 \mathrm{~d}$ (Puc. 4 r)

Fig. 4. MSCT. Axial (a), coronal (b, c), 3D reconstructions (d).

Destructive changes and sequestration are determined in the region of alveolar and palatine processes of the upper jaw with the involvement of the right frontal process.

Рис. 4. МСКт. Аксиальная (а), корональная (б, в), 3D реконструкции (г).

Определяются костно-деструктивные изменения, секвестрация в альвеолярном и небном отростках верхней челюсти с вовлечением в патологический процесс правого Аобного Аобного отростка.

bone $(\mathrm{n}=14 ; 13 \%)$. MSCT (CBCT) also made it possible to accurately assess the condition of the periodontal gap. Its expansion and sclerosis was noted in 83 patients $(76,9 \%)$. According to the MSCT (CBCT) data, the holes of the removed teeth were not detected in 71 cases $(66 \%)$, in 36 patients $(33,3 \%)$ their sclerosis was noted.

Alterations in the upper jaw, as well as development of maxillary sinusitis, were also characteristic (fig.4).

By using MSCT and CBCY the fracture line of the lower jaw was detected in $22,2 \%(n=24)$ pa- tients (fig. 5).

These high-tech methods (MSCT, CBCT) made it possible to estimate the prevalence of the pathological process on adjacent anatomical structures, which was impossible with the use of traditional $\mathrm{x}$-ray techniques. In the upper jaw of $33,3 \%$ of patients $(n=36)$, the maxillary sinus, also the zygomatic, palatal $(n=39 ; 36,1 \%)$, and in some cases the frontal processes of the maxillary bones $(n=11 ; 10,2 \%)$ were involved in the pathological process (fig.6). In 31 patients (28,7\%), according to the MSCT (CBCT), the pathological process 


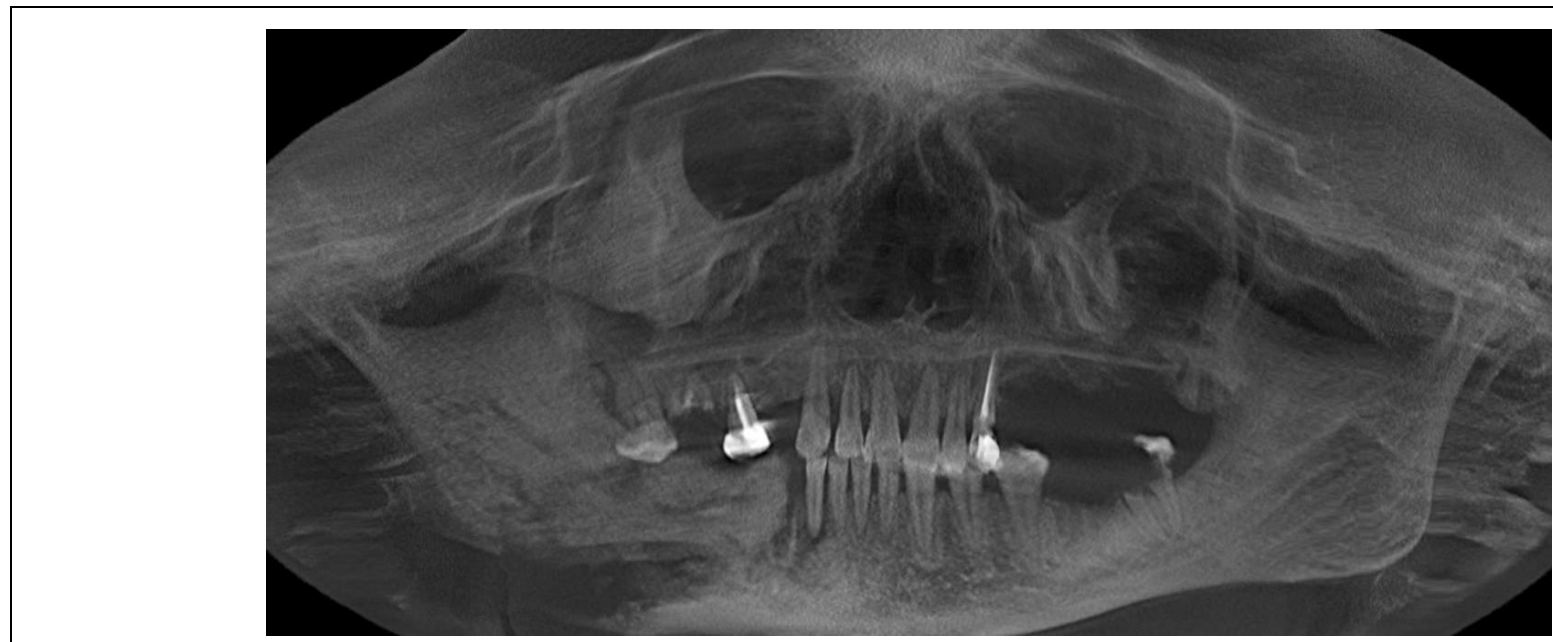

Fig. 5 a (Рис. 5 a)

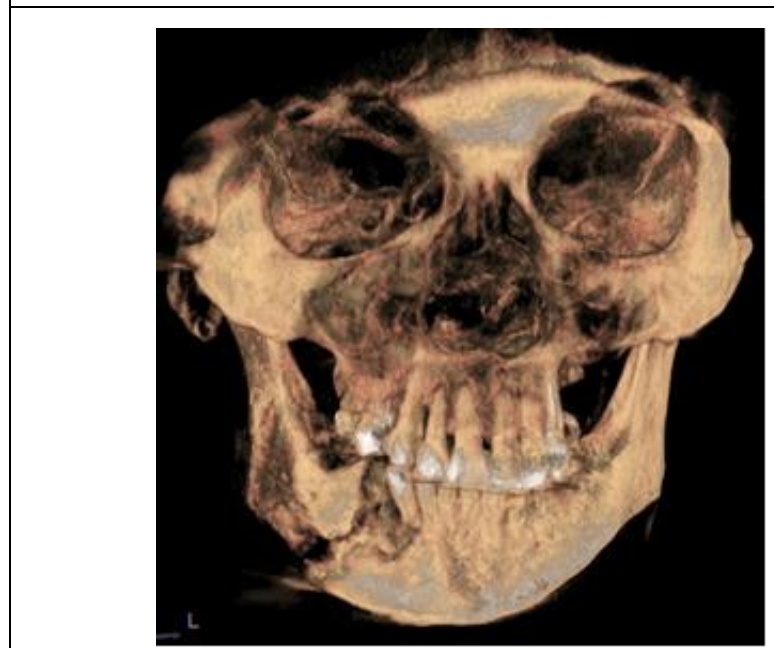

Fig. 5 b (Pис. 5 б)

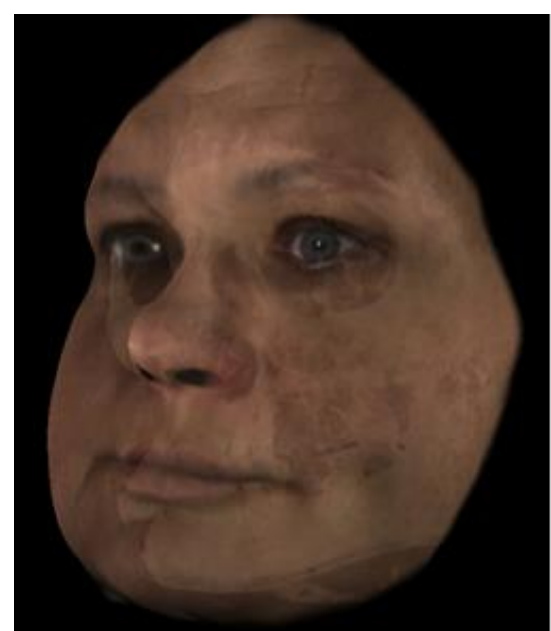

Fig. 5 с (Рис. 5 в)

\section{Fig. 5. СВCT. Panoramic (a), 3D reconstructions $(b, c)$.}

Irregular sclerosis of the body of the lower jaw to the left, body, angle, processes of the lower jaw to the right is noted. In the area of the body, the angle of the lower jaw on the right, bone-destructive changes are determined involving the right mandibular nerve, periosteal stratification, in the places of the ruptured character in the pathological process of the canal. In the area of the body of the lower jaw, the lateral tooth 4.2 determines the fracture line with displacement. Infringement of an occlusion.

\section{Рис. 5. КАКТ. Панорамная (а), 3D реконструкции (б, в).}

Визуализируется неравномерный остеоскцероз тела нижней челюсти слева, тела, угла, отростков нижней чеююсти справа. В теле, углу нижней челюсти справа отмечаются костно-деструктивные изменения с вовлечением стенок канала правого нижнечелюстного нерва, определяются периостальные наслоения местами разорванного характера. В теле нижней челюсти справа матеральнее зуба 4.2 определяется миния перелома со смещением. Визуализируется нарушение нормального прикуса.

spread to the orbital part of the frontal bone, the vascular processes of the base bone, the vomer. The method of MSCT (CBCT) allowed to assess the condition of the paranasal sinuses: to identify, characterize the presence of acute and chronic changes in the maxillary, frontal, wedge-shaped sinuses, trellis labyrinth, which can not be done by using traditional techniques. Thus, the use of MSCT (CBCT) in patients with osteonecrosis significantly complements the information on the state of bone structures and localization of the pathological process obtained with the use of traditional x-ray techniques.

At the preoperative stage of treatment 25 patients $(23,1 \%)$ underwent radionuclide diagnostics, which included two stages: planar osteoscintigraphy in the Whole Body mode, single-photon emission computed tomography (SPECT) to hip level $(n=14 ; 12,3 \%)$ or knee $(n=11 ; 10,2 \%)$. 99mTcpyrfotech was used as radiopharmaceutical (RFP). 


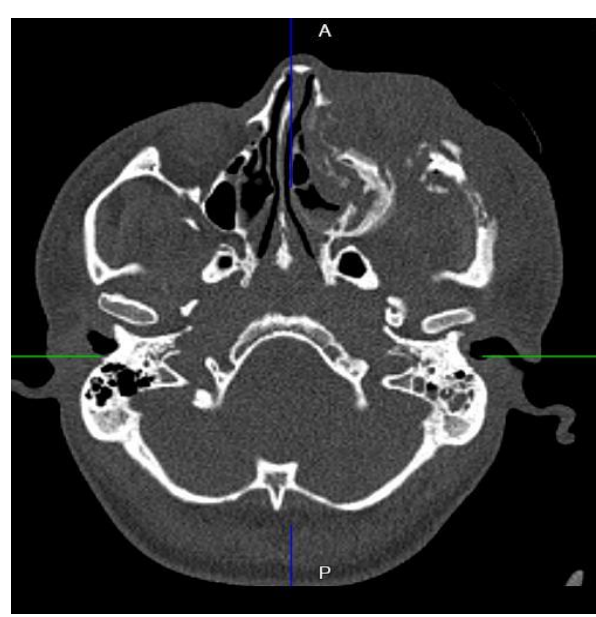

Fig. 6 a (Рис. 6 a)

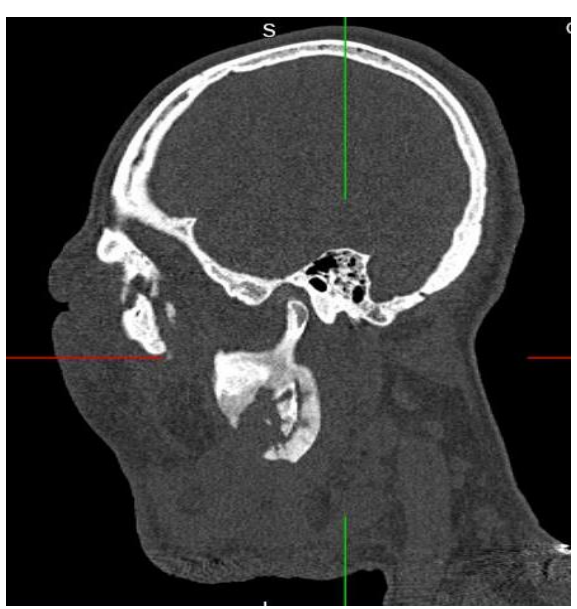

Fig. 6 с (Рис. 6 в)

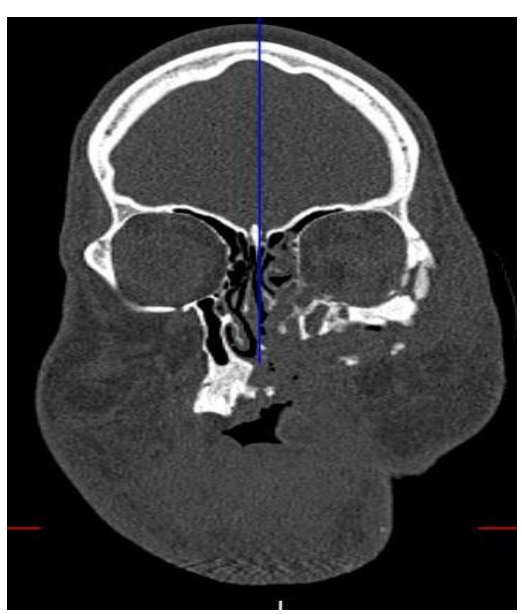

Fig. 6 b (Рис. 6 б)

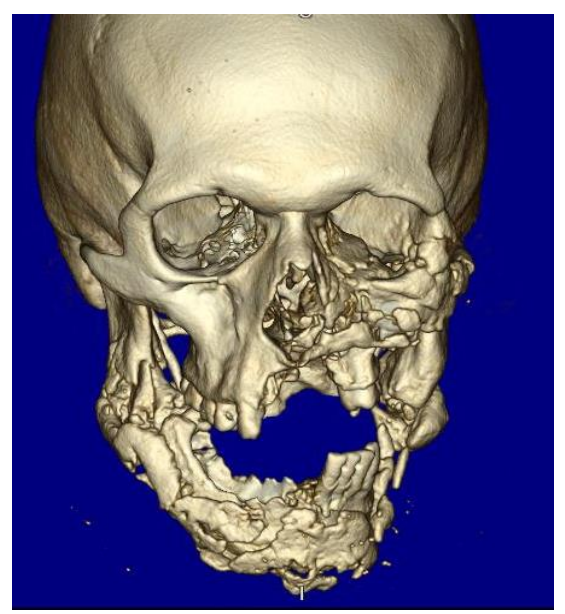

Fig. 6 d (Puc. 6 r)

Fig. 6. MSCT. Axial (a), coronal (b), sagittal (c), 3D reconstructions (d).

There are extensive bone-destructive changes in the region of the alveolar and palatine growth of the maxilla on the left, with the process of the left maxillary sinus wall extending, the left sections of the nasal cavity, the lower and lateral walls of the left orbit, the left cheekbone, the zygomatic process of the left temporal bone, the development of sequestration.

Рис. 6. МСКТ. Аксиальная (а), корональная (б), сагиттальная (в), 3D реконструкции (г).

Отмечаются выраженные костно-деструктивные изменения альвеолярного и небного отростков верхней чеАюсти слева, с распространением патологического процесса на стенки мевого верхнечелюстного синуса, $е$ вые отделы носовой полости, нижнюю и матеральную стенки мевой орбиты, мевую скуловую кость, скуловой отросток мевой височной кости, с развитием секвестрации.

When analyzing the data obtained, such indicators as intensity, localization of the accumulation of radiopharmaceutical (RFP) in the bones of both the facial and other parts of the skeleton that were included in the study area were evaluated. Evaluation was carried out visually, in collision with contralateral or lower- / higher-lying reference regions.

Bone scintigraphy and SPECT revealed excessive accumulation of the radiopharmaceutical in the facial bones in 25 study subjects: in the maxilla $(n=5 ; 4,6 \%)$, mandible $(n=11 ; 10,2 \%)$, or eye-pits in 3 patients $(2,8 \%)$ and in the cheek- bones in 4 subjects $(3,7 \%)$. Accumulation of the radiopharmaceutical was also observed in the body and manubrium of the sternum in 7 subjects $(6,5 \%)$, in the clavicles and humeral heads in 6 individuals $(5,6 \%)$ and in the crests of the ilium in 5 subjects (4,6 \%) (fig.7).

In 2 cases, a high intensity of RFP accumulation in the region of the elbow $(1,9 \%)$ or knee $(\mathrm{n}=2 ; 1,9 \%)$ joint was determined (fig.8). At the same time, no anamnestic data on the presence of trauma or signs of bone-destructive, traumatic changes in this area, obtained with the help of other X-ray diagnostic methods, were not noted. 


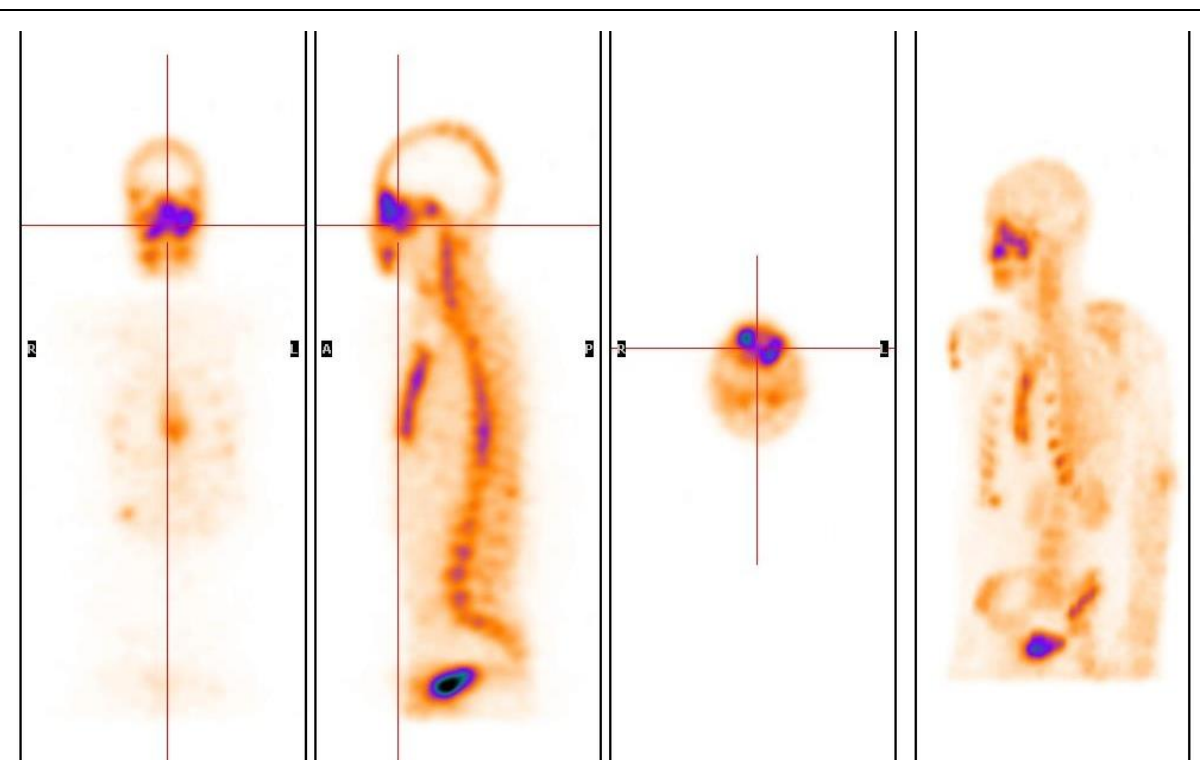

Fig. 7 (Рис. 7)

\section{Fig. 7. Bone scintigraphy, SPECT.}

Excessive accumulation of the radiopharmaceutical can be seen in the projections of the body of the upper jaw, left cheekbone - eye complex, and nasal bones, moderate accumulation of the indicator in the projections of the manubrium and body of the sternum can be observed.

\section{Рис. 7. Остеосцинтиграфия, ОФЭКт.}

Определяется интенсивное накопление радиофармпрепарата в проекции верхней челюсти, цевого скулоглазничного комплекса, костей носа, отмечается умеренное накопление РФП в проекции тела и рукоятки грудины.

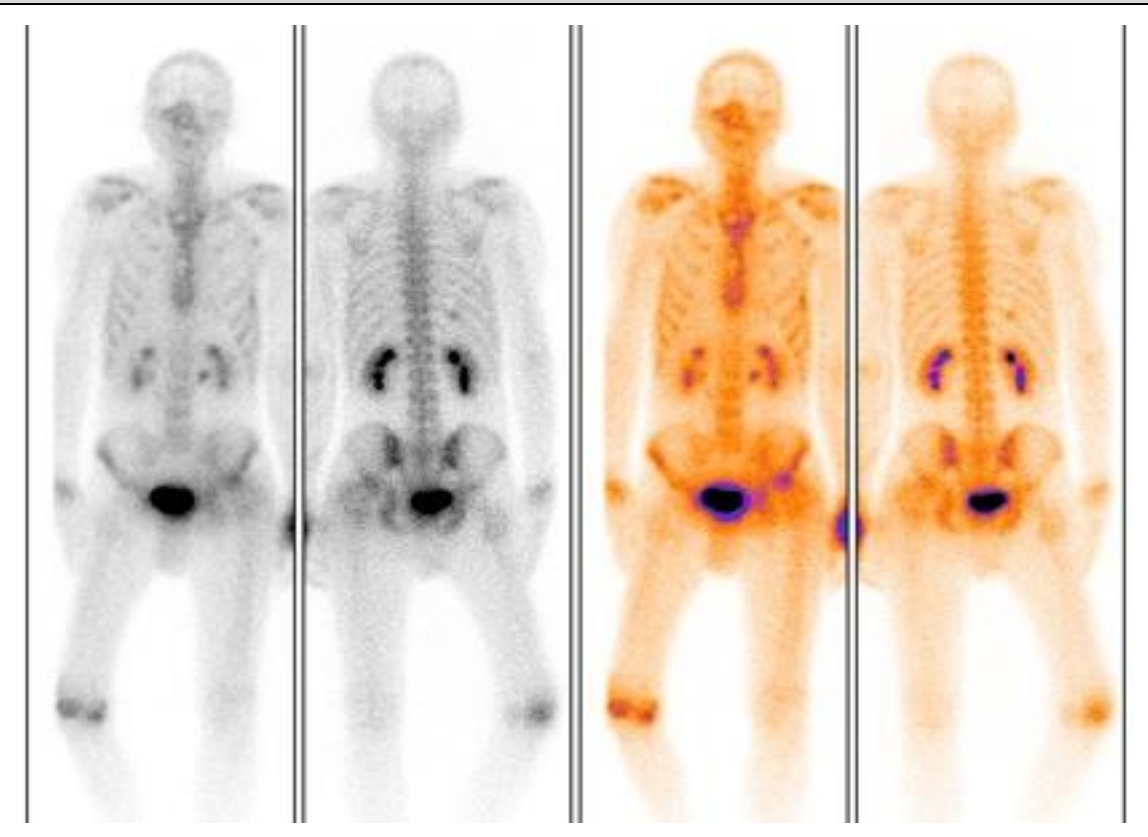

\section{Fig. 8. Bone scintigraphy.}

Areas of increased accumulation of radiopharmaceutical in the projection of the body of the upper jaw, the cheekbone, the bones of the nose to the right, the accumulation of RFP in the right knee joint, the handle and body of the sternum, the crests of the iliac bones are noted.

\section{Рис. 8. Остеосцинтиграфия.}

Визуализируется повышенное накопление РФП в проекции тела верхней челюсти, скуловой кости, костей носа справа, также отмечается аккумуляция РФП в правом коленном суставе, рукоятке и теле грудины, крыльях подвздошных костей. 


\section{RUSSIAN ELECTRONIC JOURNAL OF RADIOLOGY}

Bone scintigraphy and SPECT provided complete information on the abnormalities and allowed assessment of the regional advancement of the disease and determination of the further treatment strategy for these patients, serving as a significant addition to MSCT data.

\section{Conclusion.}

The complex radiological diagnostic routine (MSCT, radionuclide diagnostics) was conducted before surgery, which permitted use of obtained data for estimating the required scale of subsequent surgery and, in the postoperative period, for evaluation of the quality of the surgical intervention to implant individual titanium nickelide endoprostheses and for outlining further patients management plans.

Conventional X-ray techniques (orthopantomography, X-ray of the skull) allowed for a tentative, incomplete picture of the extent and nature of the pathological changes. Projective distortion summation effect, limits in the correct imaging front sections of jaws, paranasal sinuses, soft tissues, the presence of involvement in the pathological process of other facial bones skeletons did not allow to apply orthopantomography and radiography as optimal and basic methods at the preoperative stage of treatment.

Radiography skull significantly inferior orthopantomography, including determining the character changes in the wells of extracted teeth, periodontal crevices, paranasal sinuses, the nature and localization of pathological changes in the upper jaw.

In view of the availability of projection distortion superposition effect, obtaining a planar image (only in one projection) X-ray of the skull and OPG proved ineffective in the presence of associated lesions of the jaws, as with involvement in the pathological process of other facial bones of the skull.

Highly informative techniques, such as

\section{References:}

1. Basin E.M. Osteonecrosis of the bones of the facial skeleton in individuals with drug dependence (clinic, diagnostics and treatment). Author. Diss. PhD. M. 2012. (in Russian).

2. Kataev S.S., Zelenina N.B., Shilova E.A. The determination of desomorphine in the urine. Problems of expertise in medicine. 2007; 1: 32-36 (in Russian).

3. Data of the Federal service for control over drug trafficking (FSKN). Available

at:

http://www.fskn.gov.ru/includes/periodics/review/2013/121

8/181228068/detail.shtml (accessed 18 December 2013) (in Russian).

4. Babkova A.A. Complex radiological diagnosis of osteonecrosis in desomorphine dependence patients at the pre - and postoperative stages of treatment. REJR. 2016; 6 (3): 21-29 (in Russian). 5. Medvedev Yu.A., Basin E.M., Serova N.S., Korshunova A.V., Babkova A.A., Kureshova D.N. Total jaw osteonecrosis among drug addicts. Russian stomatology journal. 2016; 20 (4): 183- multislice computed tomography, cone-beam computed tomography, radionuclide diagnostic methods, diagnostic capabilities significantly outperformed conventional radiographic techniques. These methods made it possible to accurately determine the localization, the prevalence of pathological changes, to obtain the most complete information necessary for choosing the optimal tactics of surgical treatment.

$\mathrm{CBCT}$ for most parameters was not inferior to $\mathrm{MSCT}$, it also had a relatively lower radiation load. CBCT helped properly identify the characteristics of pathological changes in patients with osteonecrosis of facial bones. The disadvantage of the method was the lack of a full and correct visualization of the surrounding soft tissue, the detection of fistulous passages.

Diagnostic efficiency of methods of complex radiological diagnosis (OPG, $\mathrm{X}$-ray, MSCT, CBCT) in patients with osteonecrosis of the bones of the facial skeleton at the preoperative stage was:

- for MSCT: the sensitivity - 98,1\%, the specificity $-99,6 \%$, the accuracy $-98,8 \%$;

- for CBCT: the sensitivity - 97,3\%, the specificity $-99,1 \%$, the accuracy $-98,4 \%$;

- for orthopantomography: the sensitivity $78,6 \%$, the specificity $-76,3 \%$, the accuracy $77,4 \%$;

- for skull x-ray: the sensitivity $-61,1 \%$, the specificity $-59,2 \%$, the accuracy $-60,2 \%$.

Therefore, complex radiological diagnostic technologies (MSCT, CBCT, radionuclide diagnostics) used to evaluate the skeletal system in patients taking desomorphine allow timely identification of the nature of the disorder, its advancement, and presence of concomitant complications, thus helping in the determination of the further surgical strategy for this patient population, planning of subsequent reconstructive and rehabilitation treatment, and treatment quality assessment.

\footnotetext{
189 (in Russian).
}

6. Babkova A.A., Serova N.S., Basin E.M., Kureshova D.N., Pa sha S.P., Kornev A.I. Complex radiological diagnosis of osteonecrosis of the bones of the facial skeleton in patients who use desomorphine. REJR. 2014; 3 (2). Application: 301-302 (in Russian).

7. Serova N.S., Babkova A.A., Basin E.M., Medvedev Yu.A., Kureshova D.N., Korshunova A.V. Radiological diagnosis of "Krocodile"- associated osteonecrosis of the facial skull. REJR. 2014; 3 (2). Application: 302-303 (in Russian).

8. Ternovoy S.K., Vasilyev A.Yu. Radiological diagnostics in dentistry, Nationals guidelines on radiology and radiotherapy. Moscow, GEOTAR-Media, 2010. 288 p. (in Russian).

9. Serova N.S., Kureshova D.N., Babkova A.A., Basin E.M. Multislice computed tomography in the diagnosis of toxic phosphorus necrosis of the jaw. Vestnik rentgenologii I radiologii. 2015, 4: 11-16 (in Russian). 


\section{RUSSIAN ELECTRONIC JOURNAL OF RADIOLOGY}

10. Babkova A.A., Serova N.S., Basin E.M., Kureshova D.N., Pasha S.P., Kornev A.I. X-ray diagnosis of osteonecrosis of the bones of the facial skull in patients on the background of the use of desomorphine. REJR. 2014; 4 (2): 109-114 (in Russian)

11. Marx RE. Oral \& Intravenous Bisphosphonates-Induced Os- teonecrosis of the Jaws: History, Etiology, Prevention, and Treatment. Hanover Park, IL, Quitessence Publishing Co Inc., 2007. $160 \mathrm{p}$.

12. Serova N.S. Radiology in dental implantology. Moscow, ENoto, 2015. 220 p. (in Russian). 